\title{
A year in a Cerrado wet grassland: a non-seasonal island in a seasonal savanna environment
}

\author{
Cianciaruso, $M V *$ and Batalha, MA. \\ Departamento de Botânica, Universidade Federal de São Carlos - UFSCar, \\ CP 676, CEP 13565-905, São Carlos, SP, Brazil \\ *e-mail: cianciaruso@gmail.com \\ Received October 4, 2006 - Accepted February 9, 2007 - Distributed August 31, 2008
}

(With 1 figure)

\begin{abstract}
In some Cerrado regions where the water table is superficial and soils are hydromorphic, we may find wet grasslands. We studied temporal changes in some community descriptors, such as species density, plant density, basal area, and cylindrical volume in a Cerrado wet grassland in four different seasons of the year. We also compared the species richness and composition of the wet grassland with a hyperseasonal cerrado, and a seasonal cerrado. We found significant differences among the seasons only for species density. Chao-Sørensen similarity values varied from 0.86 to 0.99 and, in the wet grassland, were not different among the seasons. On the contrary, similarity values between the wet grassland and hyperseasonal and seasonal cerrados were low. Species richness was lower in the wet grassland and higher in the seasonal cerrado. As long as savannas are highly dynamic on all temporal and spatial scales, the wet grassland stability, at least in a short-term view, introduces an important heterogeneity in regional scale. Wet grasslands are also important in the Cerrado domain to increase $\beta$-diversity, since they are floristically dissimilar with cerrado vegetation.
\end{abstract}

Keywords: diversity, Emas National Park, savanna, seasonality, waterlogging.

\section{Um ano em um campo úmido no Cerrado: uma ilha não-estacional em um ambiente de savana estacional}

\begin{abstract}
Resumo
Dentro do domínio do Cerrado, os campos úmidos ocorrem em áreas em que o lençol freático é superficial e os solos são hidromórficos. Nosso objetivo foi estudar mudanças temporais em alguns descritores da comunidade, como riqueza de espécies, densidade de espécies, densidade de indivíduos, área basal e volume cilíndrico em um campo úmido em quatro estações do ano. Além disso, comparamos a riqueza e a composição de espécies do campo úmido com um cerrado hiperestacional e outro estacional. Encontramos diferenças significativas entre as estações apenas para a densidade de espécies. Os valores do índice de similaridade Chao-Sørensen variaram entre 0,86 e 0,99 e, no campo úmido, não foram significativamente diferentes entre as estações. Porém, a similaridade foi baixa, quando comparamos o campo úmido com os cerrados hiperestacional e estacional. A riqueza de espécies foi menor no campo úmido e maior no cerrado estacional. A estabilidade do campo úmido introduz uma heterogeneidade importante em escala regional, uma vez que as savanas são bastante dinâmicas em escalas espácio-temporais. Os campos úmidos são importantes no domínio do Cerrado por aumentarem a diversidade $\beta$, já que são dissimilares em relação ao cerrado.
\end{abstract}

Palavras-chave: diversidade, Parque Nacional das Emas, savana, estacionalidade, alagamento.

\section{Introduction}

Seasonal variations in climate and life cycles occur in all communities, even in those apparently stable, such as tropical rain forests (Walker and Noy-Meir, 1982). However, it is in tropical savannas that seasonality becomes marked to such an extent that savanna species are not only adapted to survive such variations but require such variations to maintain their resilience (Walker and Noy-Meir, 1982). In addition to the spatial heterogeneity associated with soil-catena effects, there are other com- munities within the widespread matrix of woody-grass combinations that are determined by special conditions, such as wetlands, wet grasslands, gallery forests, and semideciduous forests (Pivello and Coutinho, 1996; Walker, 2001). Although these communities generally occupy only a small fraction of the savanna domain, they play a disproportionately important role in contributing to regional biodiversity in two ways: they have their own unique species and they serve as crucial refugia, 
providing food or shelter at critical times of the year for the widespread savanna species (Stafford-Smith and Morton, 1990).

The Brazilian savanna domain, commonly known as Cerrado, once covered approximately $22 \%$ of the Brazilian territory and is a biological diversity hotspot (Silva and Bates, 2002). Cerrado climate is typically seasonal, with a conspicuous contrast between the dry and rainy seasons (Ferreira et al., 2003). The strong seasonal climate, together with nutrient-poor, aluminiumrich soils, and frequent fires, has imposed environmental pressures on the Cerrado domain (Pivello and Coutinho, 1996; Ferreira et al., 2003), resulting in a wide range of adaptive, phenological strategies, and a rich phytogeographical region of landcover types and biodiversity (Ratter et al., 1997; Ribeiro and Walter, 1998).

In some regions within the Cerrado domain, where the water table is superficial and soils are hydromorphic, we may find wet grasslands (Ratter et al., 1997; Ribeiro and Walter, 1998; Batalha and Martins, 2002). They are strictly herbaceous communities established in poorly drained bottomlands or depressed regions with slow and ill-defined drainage (Sarmiento, 1983; Ratter et al., 1997). These areas are frequently found associated to watercourses or occupying depressed regions, occurring as a belt between cerrado and gallery forest, where the water table is near the surface for most or all of the year (Sarmiento, 1983; Ratter et al., 1997).

When a community persists in time, we say that it is stable (Archer et al., 1996). Stability may be the result of an invariant environment or it may be due to the ability of species populations to persist even when external conditions change (Archer et al., 1996). Stability can be exhibited by different community properties, such as floristic composition, species diversity, demographic patterns, total biomass, cover, and similar system properties (Archer et al., 1996). The nature of the above-ground community may be an important determinant of the consistency of delivery of community services: for example, changes in above-ground structure may have important effects on the below-ground response to drought and, thus, influence community stability (Wardle et al., 2000).

In previous studies in the hyperseasonal and seasonal cerrados of Emas National Park, with the same experimental design used here, we found that these communities are highly dynamic on the temporal scale, in which short-term changes, especially plant-available moisture, modify its physiognomy, specific composition, and ecological processes throughout the year (Cianciaruso et al., 2005; M. Cianciaruso, unpublished data). Although wetlands may be unstable and dynamic per se due to accentuated changes in water flow in flat areas (Maltby, 1986), we may expect more stable conditions throughout the year in Cerrado wet grasslands, since they are always or almost always waterlogged (Sarmiento, 1983). So, we tried to answer the following questions: i) does the above-ground floristic composition remain constant throughout the year in the wet grassland?; ii) do species density, plant density, basal area, and cylindrical volume remain constant throughout the year in the wet grassland?; and iii) are these patterns similar when compared to those found in nearby seasonal and hyperseasonal cerrados (Cianciaruso et al., 2005; M. Cianciaruso, unpublished data)?

\section{Materials and Methods}

The Emas National Park (ENP) comprises 132,941 ha and is located in the Brazilian Central Plateau, southwestern Goiás State $\left(17^{\circ} 49^{\prime}-18^{\circ} 28^{\prime} \mathrm{S}\right.$ and $\left.52^{\circ} 39^{\prime}-53^{\circ} 10^{\prime} \mathrm{W}\right)$. Regional climate is classified as Aw according to Köppen (1931), being humid tropical with wet summer and dry winter. Annual rainfall varies from 1,200 to $2,000 \mathrm{~mm}$, concentrated from October to March, and mean annual temperature lies around $24.6^{\circ} \mathrm{C}$ (Ramos-Neto and Pivello, 2000). Three quarters of the ENP consist of flat tableland, at an altitude of 820-888 m, and the remaining area consists of hilly terrain, at an altitude of 720-820 m (Ramos-Neto and Pivello, 2000). Wild-fires are common and about every three years the park experiences a large fire (Silveira et al., 1999). In the reserve, open cerrado physiognomies - campo limpo, campo sujo, and campo cerrado - prevail, covering $68.1 \%$ of the total area, especially on the flat tableland (Ramos-Neto and Pivello 2000). The more closed cerrado sensu stricto covers $25.1 \%$ of the reserve, mainly on the hilly terrain. Other vegetation types, such as wet grasslands ( $4.9 \%$ of the total area) and riparian and seasonal semideciduous forests $(1.2 \%)$, also exist within the park.

We carried out four surveys in a wet grassland located close to the southwestern edge of ENP: in February 2003, in mid rainy season, when the wet grassland was waterlogged; in May 2003, in late rainy season, with the superficial soil layer saturated but without standing water; in August 2003, in the dry season, when superficial soil layer was moist at depths below $20 \mathrm{~cm}$ (M. Cianciaruso, pers. obs.); and in November 2003, in early rainy season, with the superficial soil layer as saturated as in May. We established a 1 ha area (approximately, $18^{\circ} 15^{\prime} 40^{\prime \prime} \mathrm{S}$ and $53^{\circ} 01^{\prime} 08^{\prime \prime} \mathrm{W}$ ), and, in each field trip, by using random coordinates $(\mathrm{x}, \mathrm{y})$ in a Cartesian plane, we placed ten $1 \mathrm{~m}^{2}$ quadrats, in which we sampled, except for seedlings, all vascular plants with above-ground portions, since above-ground community is a good indicator of several community processes (Wardle et al., 2000; Buonopane et al., 2005). For each individual, we measured height and diameter at soil level, and counted the number of individuals belonging to each species. In the case of cespitose grasses, we considered as an individual the whole tuft. We identified the species by comparing the collected material to vouchers lodged at São Paulo State Botanical Institute and Brazilian Institute of Geography and Statistics herbaria. When identification at species level was not possible, we or the taxonomists classified them as morphospecies. 
We analyzed the following variables: species richness, species density, plant density, basal area, and cylindrical volume. We defined species density as the number of species per area (spp. $\left.\mathrm{m}^{-2}\right)$; plant density as the number of individuals per area (ind $\mathrm{m}^{-2}$ ); basal area as the area covered by each species $\left(\mathrm{m}^{2} \mathrm{~m}^{-2}\right)$; and cylindrical volume as the volume occupied by each species $\left(\mathrm{m}^{3} \mathrm{~m}^{-2}\right)$, according to Mueller-Dombois and Ellenberg (1974). We used analyses of variance and the Tukey multiple comparison test (Zar, 1999) to test for significant differences $(\alpha=0.05)$ among the seasons.

We estimated floristic similarity among the seasons with the abundance-based Chao estimator for Sørensen index (Chao-Sørensen), which reduces undersampling bias by estimating and compensating for the effects of unseen, shared species (Chao et al., 2005). This index is better suited than the corresponding classic Sørensen index for assessing compositional similarity between samples that differ in size, are known or suspected to be undersampled, or are likely to contain numerous rare species (Chao et al., 2005). We calculated the Chao-Sørensen index with 95 percent confidence intervals (CI), using the EstimateS 7.5 software (Colwell, 2005). We calculated an individual-based curve with 95 percent CI curves using the $S_{\text {obs }}$ (Mao-Tau) function (Colwell et al., 2004) to compare the overall number of species (i.e., all the species we found in the four field trips) among the wet grassland, a nearby seasonal cerrado (M. Cianciaruso, unpublished data), and a nearby hyperseasonal cerrado (Cianciaruso et al., 2005), using EstimateS 7.5 software (Colwell, 2005). If the confidence intervals were not overlapped, we considered the difference significant. We also calculated floristic similarity among these vegetation forms with the Chao-Sørensen index (Chao et al., 2005).

\section{Results}

Using the floristic data from all field trips, we found 45 species from 16 families in the wet grassland (Table 1), of which 38 species and 5 families (Droseraceae, Ericaceae, Eriocaulaceae, Lycopodiaceae, and Xyridaceae) were not previously related in ENP's flora (Batalha and Martins, 2002). The richest families were Poaceae and Cyperaceae, followed by Xyridaceae, Melastomataceae, and Euphorbiaceae. In all seasons, the most abundant species were Rhynchospora globosa (Kunth) Roem. and Schult and Schizachyrium tenerum Nees.

In February, during mid rainy season, we found 2,276 individuals and 32 species; in May, in late rainy season, we found 2,530 individuals and 32 species; in August, during the dry season, we found 2,516 individuals and 28 species; in November, in early rainy season, we found 2,664 individuals and 27 species. In August, we found 46 individuals completely dried or 1.8 percent of total individuals. Rhynchospora globosa was the most affected species (4 percent of the total number of individuals was dried in this season), followed by Axonopus brasiliensis (Spreng.) Kuhlm. (1.7\%), Elionurus muticus (Spreng.) Kuntze (1.3\%), and Sisyrinchium vaginatum Spreng (1.4\%). Chao-Sørensen similarity values varied from 0.86 to 0.99 and were not different among the seasons (Table 2).

We found significant differences among the seasons only for species density, lower in early rainy season and higher in mid rainy season (Table 3). We did not find significant differences among the seasons for species richness, plant density, basal area, and cylindrical volume (Table 3). Species richness was lower in the wet grassland (45 species), intermediate in the hyperseasonal cerrado (65), and higher in the seasonal cerrado (107) (Figure 1). Similarity was lower between wet grassland and hyperseasonal and seasonal cerrados $(0.01 \pm 0.02$ and $0.08 \pm 0.08$, respectively), but higher between both cerrado forms $(0.88 \pm 0.12)$.

\section{Discussion}

The many species not previously reported in ENP's flora corroborated Batalha and Martins (2002), who stated that the number of species in ENP could increase, since they only surveyed the cerrado vegetation and not the other vegetation types existing within the reserve, such as the wet grasslands. Many species of the wet grassland belong to genera commonly found in other wet grasslands, such as Rhynchospora (Cyperaceae), Drosera (Droseraceae), Sisyrinchium (Iridaceae), and Aristida, Panicum, Paspalum, and Trachypogon (Poaceae) (Ribeiro and Walter, 1998). One species is also found in gallery forests within the Cerrado domain and eight may also occur not only in wet grasslands but also in other cerrado physiognomies (Table 1). Moreover, we found seven species that do not appear in the checklist of the Cerrado domain vascular flora (Mendonça et al., 1998).

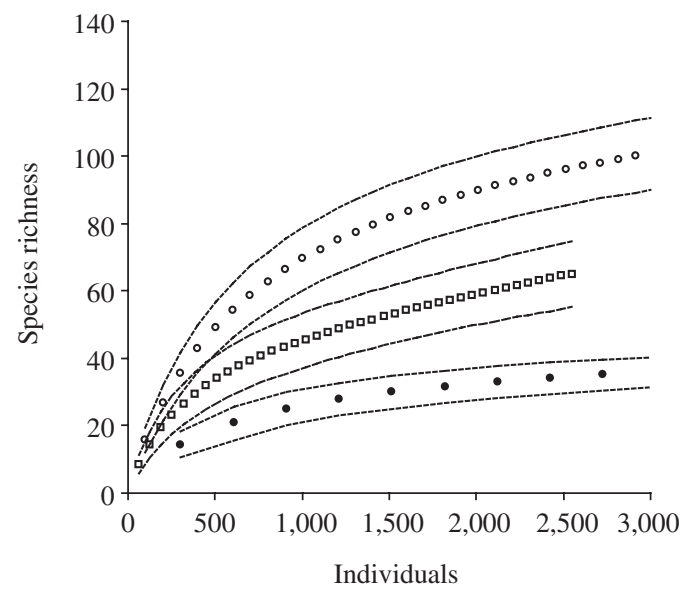

Figure 1. Species richness versus number of individuals in the wet grassland (closed circles), hyperseasonal cerrado (open squares) and seasonal cerrado (open circles), Emas National Park, Goiás, central Brazil. Dash lines are \pm 95 percent confidence intervals. 
Table 1. Species and number of individuals found in the wet grassland ( $18^{\circ} 15^{\prime} 40^{\prime \prime} \mathrm{S}$ and $\left.53^{\circ} 01^{\prime} 08^{\prime \prime} \mathrm{W}\right)$, Emas National Park, Goiás, central Brazil. Feb = mid rainy season, May = late rainy season; Aug = dry season, Nov = early rainy season.

\begin{tabular}{|c|c|c|c|c|}
\hline Family/Species & Feb./03 & May/03 & Aug./03 & Nov./03 \\
\hline \multicolumn{5}{|l|}{ CYPERACEAE } \\
\hline Cyperus haspan $\mathrm{L}^{\mathrm{a}}$ & 12 & 34 & 29 & 49 \\
\hline Exochogyne amazonica C.B. Clarke ${ }^{\mathrm{a}, \mathrm{b}}$ & 1 & - & - & - \\
\hline Fimbristylis dichotoma $(\mathrm{L}$.$) Vahl ^{\mathrm{a}}$ & 1 & 1 & - & - \\
\hline Rhynchospora diamantina (C.B. Clarke) Kükenth & 31 & - & - & - \\
\hline Rhynchospora globosa (Kunth) Roem. and Schult. ${ }^{\mathrm{a}}$ & 926 & 882 & 827 & 1632 \\
\hline \multicolumn{5}{|l|}{ DROSERACEAE } \\
\hline Drosera communis A. St-Hil ${ }^{\mathrm{a}}$ & 3 & - & - & - \\
\hline \multicolumn{5}{|l|}{ ERICACEAE } \\
\hline Gaylussacia brasiliensis (Spreng.) Meisn. ${ }^{\mathrm{a}, \mathrm{c}}$ & 58 & 16 & 1 & 31 \\
\hline \multicolumn{5}{|l|}{ ERIOCAULACEAE } \\
\hline Syngonanthus xeranthemoides (Bong.) Ruhland. ${ }^{a}$ & 83 & 456 & 114 & 150 \\
\hline \multicolumn{5}{|l|}{ EUPHORBIACEAE } \\
\hline Croton glandulosus Müll. Arg. ${ }^{\mathrm{b}, \mathrm{d}}$ & 200 & 78 & 3 & 124 \\
\hline Phyllanthus niruni L. ${ }^{\mathrm{a}, \mathrm{d}}$ & 28 & 12 & 4 & 3 \\
\hline \multicolumn{5}{|l|}{ GENTIANACEAE } \\
\hline Irlbachia caerulescens (Aubl.) Griseb. ${ }^{\mathrm{a}}$ & 4 & 15 & - & 18 \\
\hline \multicolumn{5}{|l|}{ HYPOXIDACEAE } \\
\hline Hypoxis sp. $^{\mathrm{a}}$ & 5 & - & - & - \\
\hline \multicolumn{5}{|l|}{ IRIDACEAE } \\
\hline Sisyrinchium vaginatum Spreng $^{\mathrm{d}}$ & 19 & 308 & 142 & 11 \\
\hline \multicolumn{5}{|l|}{ LAMIACEAE } \\
\hline Hyptis pulchella Briq. ${ }^{\mathrm{a}, \mathrm{b}}$ & 11 & 15 & 4 & 13 \\
\hline \multicolumn{5}{|l|}{ LYCOPODIACEAE } \\
\hline Lycopodiella cernua (L.) Pic.Serm. ${ }^{\mathrm{a}, \mathrm{b}}$ & 2 & 5 & 36 & 18 \\
\hline \multicolumn{5}{|l|}{ LYTHRACEAE } \\
\hline Cuphea sp. ${ }^{\mathrm{a}}$ & 7 & 2 & 2 & - \\
\hline \multicolumn{5}{|l|}{ MELASTOMATACEAE } \\
\hline Acisanthera sp. ${ }^{\mathrm{a}}$ & 1 & 4 & 2 & 7 \\
\hline Pterolepsis repanda Triana $^{\mathrm{a}, \mathrm{d}}$ & 13 & 5 & 13 & - \\
\hline Melastomataceae sp. $1^{\mathrm{a}}$ & - & - & 1 & - \\
\hline \multicolumn{5}{|l|}{ POACEAE } \\
\hline Andropogon selloanus (Hack.) Hack. & - & - & 7 & - \\
\hline Aristida jubata (Arechav.) Herter a,d & - & 10 & & - \\
\hline Axonopus brasiliensis (Spreng.) Kuhlm. & - & 12 & 239 & 1 \\
\hline Axonopus comans (Trin.) Kuhlm. ${ }^{a}$ & 14 & 32 & 8 & 6 \\
\hline Elionurus latiflorus $\mathrm{Nees}^{\mathrm{d}}$ & 1 & - & - & - \\
\hline Elionurus muticus (Spreng.) Kuntze ${ }^{\mathrm{a}}$ & - & - & 78 & - \\
\hline Eragrostis bahiensis Schrad ex. Schult a,b & 13 & 5 & - & 10 \\
\hline Gymnopogon foliosus (Willd.) Nees ${ }^{\mathrm{d}}$ & - & 6 & - & - \\
\hline Leptosaccharum filiforme Hack. ${ }^{\mathrm{a}, \mathrm{b}}$ & - & - & 207 & - \\
\hline Panicum hians Elliot. ${ }^{a}$ & 5 & 1 & 11 & 4 \\
\hline Paspalum dedeccae Quarin $^{\mathrm{a}}$ & 50 & 35 & 143 & - \\
\hline Paspalum maculosum Trin ${ }^{\mathrm{a}, \mathrm{d}}$ & 57 & 55 & 176 & 27 \\
\hline Poaceae sp. $1^{\mathrm{a}}$ & - & - & 1 & - \\
\hline Poaceae sp. $2^{\mathrm{a}}$ & - & 3 & - & - \\
\hline Schizacchirium tenerum Nees $^{\mathrm{a}, \mathrm{d}}$ & 352 & 367 & 354 & 366 \\
\hline
\end{tabular}


Table 1. Continued...

\begin{tabular}{|c|c|c|c|c|}
\hline Family/Species & Feb./03 & Mar./03 & Aug./03 & Nov./03 \\
\hline Trachypogon sp. ${ }^{\mathrm{a}}$ & 5 & 71 & 20 & 30 \\
\hline \multicolumn{5}{|l|}{ RUBIACEAE } \\
\hline Coccocypselum lymansmithii Standl. ${ }^{\mathrm{a}}$ & 22 & 32 & 4 & 35 \\
\hline \multicolumn{5}{|l|}{ UNKNOWN } \\
\hline Unknown sp. $1^{\mathrm{a}}$ & 4 & - & - & 1 \\
\hline Unknown sp. $2^{\mathrm{a}}$ & 7 & - & 10 & 2 \\
\hline Unknown sp. $3^{\mathrm{a}}$ & 100 & 4 & 3 & 6 \\
\hline Unknown sp. $4^{\mathrm{a}}$ & - & 1 & - & - \\
\hline Unknown sp. $5^{\mathrm{a}}$ & 92 & 17 & - & 21 \\
\hline Unknown sp. $6^{\mathrm{a}}$ & & 13 & - & 3 \\
\hline \multicolumn{5}{|l|}{ VERBENACEAE } \\
\hline Stachytarpheta linearis Moldenke $e^{\mathrm{a}, \mathrm{b}}$ & 8 & 2 & - & - \\
\hline \multicolumn{5}{|l|}{ XYRIDACEAE } \\
\hline Abolboda sp. ${ }^{\mathrm{a}}$ & - & - & - & 6 \\
\hline Xyris sp. $1^{\mathrm{a}}$ & 142 & 31 & 77 & 86 \\
\hline
\end{tabular}

${ }^{\mathrm{a}}=$ addition to ENP's flora, that is, species not reported by Batalha and Martins (2002), ${ }^{\mathrm{b}}=$ addition to Cerrado vascular flora checklist, that is, species not reported by Mendonça et al. (1998), ${ }^{\mathrm{c}}=$ also occurring in cerrado gallery forests (Mendonça et al. 1998), and ${ }^{\mathrm{d}}=$ may occur in cerrado physiognomies (savannas) (Mendonça et al. 1998).

Table 2. Compositional similarity among seasons in the wet grassland (approximately, $18^{\circ} 15^{\prime} 40^{\prime \prime} \mathrm{S}$ and $53^{\circ} 01^{\prime} 08^{\prime \prime} \mathrm{W}$ ), Emas National Park, central Brazil. February corresponds to mid rainy season, May corresponds to late rainy season, August corresponds to dry season, and November corresponds to early rainy season. Values are abundance-based Chao-Sørensen index \pm 95 percent confidence intervals.

\begin{tabular}{lccc}
\hline & May & August & November \\
\hline February & $0.98 \pm 0.04$ & $0.86 \pm 0.22$ & $0.97 \pm 0.05$ \\
May & - & $0.92 \pm 0.12$ & $0.99 \pm 0.03$ \\
August & - & - & $0.92 \pm 0.17$ \\
\hline
\end{tabular}

Wet grasslands are, thus, important in the Cerrado domain to increase $\beta$-diversity.

It has been argued that, as a general rule, equilibrium dynamics are driven by grazing and species interaction in wet grasslands, whereas, under more arid conditions, non-equilibrium dynamics are controlled by environmental factors, especially soil and moisture (Tainton et al., 1996). The Cerrado wet grassland community is stable and seems to be in equilibrium dynamics, at least in a short-term view, since we did not find significant changes in floristic composition, plant density, basal area, and cylindrical volume throughout the year. In fact, only species density changed between mid and early rainy seasons, when the increase in the number of Rhynchospora globosa individuals probably implied a decrease in species density. Other species, such as Syngonanthus xeranthemoides, Sisyrinchium vaginatum, and Axonopus brasiliensis, presented a markedly seasonal occurrence, but not sufficient to change community similarity and structure among the seasons - except for species density, as already mentioned.

Cerrado wet grasslands are always or almost always waterlogged (Sarmiento, 1983). In the dry season, besides the water moisture reduction in superficial soil layers, we noticed humidity below $20 \mathrm{~cm}$ deep (M. Cianciaruso, pers. obs.). Graminoids species, with an intensive root system, exploit the upper soil layers (Medina and Silva, 1990). In savannas, the herbaceous component presents its largest development in late rainy season and lowest during the dry season (Sarmiento, 1983; Cianciaruso et al., 2005), which is related with soil plant available moisture (Sarmiento, 1983). In wet grasslands, however, even though we found some dried individuals of four species in the dry season, we may postulate that the stability of most structure descriptors is due to water availability throughout the year.

On the contrary, in the cerrados of ENP, there is a non-equilibrium dynamics, in which the drought imposed by the dry season reduces their diversity, plant density, and biomass and changes their floristic composition throughout the year (Cianciaruso et al., 2005; M. Cianciaruso, unpublished data). The hyperseasonal cerrado is more dynamic than the seasonal cerrado due to the waterlogging in mid rainy season (Batalha et al., 2005; Cianciaruso et al., 2005; M. Cianciaruso, unpublished data). Waterlogging reduces species and plant density, whereas drought reduces diversity in the hyperseasonal cerrado, but in early rainy season species density, plant density, and diversity increase (Cianciaruso et al., 2005).

The wet grassland has less species than the nearby seasonal and hyperseasonal cerrados (Cianciaruso et al., 
Table 3. Species density $\left(\mathrm{spp} . \mathrm{m}^{-2}\right)$, plant density $\left(\right.$ ind $\left.\mathrm{m}^{-2}\right)$, basal area $\left(\mathrm{m}^{2} \mathrm{~m}^{-2}\right)$, and cylindrical volume $\left(\mathrm{m}^{3} \mathrm{~m}^{-2}\right)$ throughout the year in the wet grassland ( $18^{\circ} 15^{\prime} 40^{\prime \prime} \mathrm{S}$ and $53^{\circ} 01^{\prime}$ 0 $8^{\prime \prime} \mathrm{W}$ ), Emas National Park, central Brazil. February corresponds to mid rainy season, May corresponds to late rainy season, August corresponds to dry season, and November corresponds to early rainy season. The values are means \pm standard deviations. Different letters indicate significant differences $(\alpha=0.05)$.

\begin{tabular}{lcccccc}
\hline \multicolumn{1}{c}{ Descriptor } & February & May & August & November & F & P \\
\hline Species density & $17.10^{\mathrm{a}} \pm 3.57$ & $13.20^{\mathrm{a}, \mathrm{b}} \pm 3.26$ & $14.00^{\mathrm{a}, \mathrm{b}} \pm 2.45$ & $11.00^{\mathrm{b}} \pm 3.53$ & 5.770 & $<0.001$ \\
Plant density & $227.60 \pm 45.75$ & $253.00 \pm 119.62$ & $251.60 \pm 96.42$ & $266.40 \pm 101.14$ & 0.640 & 0.640 \\
Basal area & $0.030 \pm 0.015$ & $0.025 \pm 0.008$ & $0.027 \pm 0.010$ & $0.018 \pm 0.004$ & 2.060 & 0.101 \\
Cylindrical volume & $0.018 \pm 0.009$ & $0.014 \pm 0.003$ & $0.017 \pm 0.007$ & $0.012 \pm 0.003$ & 2.010 & 0.100 \\
\hline
\end{tabular}

2005; Batalha et al., 2005; M. Cianciaruso, unpublished data) and is very dissimilar. Law and Morton (1996) suggested that there is a one-to-one match between environment and community. In this case, local diversity $(\alpha$-diversity) and composition are the result of regional species pool ( $\gamma$-diversity) and environmental filters (Chase, 2003). So, waterlogging duration in the wet grassland should be severe enough to not allow the survival of inferior competitors of the regional pool of species and to support a distinct flora. Although some typical cerrado species can survive under a short waterlogging period (Batalha et al., 2005; Cianciaruso et al., 2005), the extended waterlogging period in the wet grassland is severe enough to act as an environmental filter (Chase, 2003), restricting the number of species of regional pool able to survive under these conditions.

Water holes are essential in seasonally dry habitats (Ojasti, 1983). The fact that the wet grassland community is stable introduces an important heterogeneity on a regional scale, since savannas are highly dynamic on all temporal and spatial scales, with long- and shortterm changes (e.g., fire and plant available moisture) constantly modifying their physiognomy, composition, and ecological processes (Hopkins, 1983; Walker, 1987). Within the cerrado domain, gallery forests provide refuge, food, and water for species not confined to forests (Redford and Fonseca, 1986). The same may hold true for wet grasslands, since they occur as narrow belts in the forest-savanna boundary (Sarmiento, 1983). In ENP particularly, wet grasslands are extremely important, since the reserve is located above the Guarani aquifer, one of the largest aquifers in the world with potable water, which has recharging areas within ENP and its surroundings (Embrapa, 1999).

According to our results, wet grasslands within the cerrado domain are floristically and structurally stable throughout the year. So, wet grasslands may be important in providing resources and refuge to cerrado fauna species, some of which are threatened by extinction, during the dry season, which may last up to six months (Ratter et al., 1997) and during fires, which are frequent in the cerrado vegetation (Coutinho, 1990), especially in ENP (Ramos-Neto and Pivello, 2000). Considering the importance of its particular flora, which enhances regional diversity and its importance as a water outcrop, we expect that the cerrado wet grasslands will be given more attention, both scientific and political. The cerrado wet grasslands are non-seasonal islands in a seasonal sea, and therefore, a key factor in the maintenance of the high biodiversity of the Brazilian cerrado domain.

Acknowledgements - We are grateful to Fapesp, for financial support; to Capes, for the scholarship granted to the first author; to Ibama, for research permission; to the Emas National Park staff, for logistical assistance; to P.K. Amorim, C.A. Casali, A.V. Fleuri-Jardim, H.F. Lima, R.A. Miotto, F. Oliveira, I.A. Silva, O.L. Silva, and M.W. Valenti, for friendship and help in field; to T.S. Filgueiras, R.C. Oliveira, M.A. Silva and R.M. Harley, for their assistance in species identification; to R. Chazdon, A.V. Fleuri-Jardim, I.A. Silva; and to an anonymous referee, for constructive suggestions.

\section{References}

ARCHER, S., COUGHNOUR, M., DALL'AGLIO, C., FERNANDEZ, GW., HAY, J., HOFFMANN, W., KLINK, C., SILVA, JF. and SOLBRIG, OT., 1996. Savanna biodiversity and ecosystem properties. In SOLBRIG, OT., MEDINA, E. and SILVA, JF. (Ed.). Biodiversity and savanna ecosystem processes. Berlin: Springer. p. 207-218.

BATALHA, MA. and MARTINS, FR., 2002. The vascular flora of the cerrado in Emas National Park (Goiás, Central Brazil). Sida, vol. 20, no. 1, p. 295-311.

BATALHA, MA., CIANCIARUSO, MV., SILVA, IA, and DELITTI, WCB., 2005. Hyperseasonal cerrado, a new Brazilian vegetation form. Braz. J. Biol. $=$ Rev. Bras. Biol., vol. 65, no. 4, p. $735-738$.

BUONOPANE, M., HUENNEKE, LF. and REMMENGA, M., 2005. Community response to removals of plant functional groups and species from a Chihuahuan Desert shrubland. Oikos, vol. 110 , no. 1, p. 67-80.

CHAO, A., CHAZDON, RL., COLWELL, RK. and SHEN, TJ., 2005. A new statistical approach for assessing compositional similarity based on incidence and abundance data. Ecol. Lett., vol. 8, no. 2, p. 148-159.

CHASE, JM., 2003. Community assembly: when should history matter? Oecologia, vol. 136, no. 4, p. 489-498.

CIANCIARUSO, MV., BATALHA, MA., SILVA, IA., 2005. Seasonal variation of a hyperseasonal cerrado in Emas National Park, central Brazil. Flora, vol. 200, no. 4, p. 345-353.

COLWELL, RK., MAO, CX. and CHANG, J., 2004. Interpolating, extrapolating, and comparing incidence- 
based species accumulation curves. Ecology, vol. 85, no. 10, p. 2717-2727.

COLWELL, RK., 2005. EstimateS: Statistical estimation of species richness and shared species from samples. Version 8.0. User's Guide and application. [07/18/2008]. Available from: http://purl.oclc.org/estimates.

COUTINHO, LM., 1990. Fire in the ecology of the Brazilian cerrado. In GOLDAMMER, JG. (Ed.). Fire in the tropical biota. Berlin: Springer. p. 81-103.

EMBRAPA - EMPRESA BRASILEIRA DE PESQUISA AGROPECUÁRIA, 1999. Gestão dos Recursos Hídricos das Microbacias dos Rios Araguaia, Taquari e Sucuriú. Jaguariúna: Centro Nacional de Pesquisa, Monitoramento e Avaliação de Impacto Ambiental.

FERREIRA, LG., YOSHIOKA, H., HUETE, A. and SANO, EE., 2003. Seasonal landscape and spectral vegetation index dynamics in the Brazilian Cerrado: An analysis within the Large-Scale Biosphere-Atmosphere Experiment in Amazônia (LBA). Rem. Sens. Environ., vol. 87, no. 4, p. 534-550.

HOPKINS, B., 1983. Successional processes. In GOODALL, DW. (Ed.). Ecosystems of the world: tropical savannas. Amsterdam: Elsevier., p. 605-617.

KÖPPEN, W., 1931. Grundriss der Klimakunde. Berlin: Gruyter.

LAW, R. and MORTON, MD., 1996. Permanence and the assembly of ecological communities. Ecology, vol. 77, no. 3, p. 762-775.

MALTBY, E., 1986. Waterlogged wealth - Why waste the world's wet places? London: Earthscan.

MEDINA, E. and SILVA, J., 1990. Savannas of northern South America: a steady state regulated by water-fire interactions on a background of low nutrient availability. J. Biogeogr., vol. 17, no. 4-5, p. 403-413.

MENDONÇA, RC., FELFILI, JM., WALTER, BMT., SILVAJÚNIOR, MC., REZENDE, AV., FILGUEIRAS, TS. and NOGUEIRA, PE., 1998. Flora vascular do Cerrado. In Sano, SM. and Almeida, SP. (Ed.). Cerrado: ambiente e flora. Brasília: Embrapa. p. 199-556.

MUELLER-DOMBOIS, D. and ELLENBERG, H. 1974. Aims and methods of vegetation ecology. New York: John Willey \& Sons.

OJASTI, J., 1983. Ungulates and large rodents of South America. In GOODALL, D.W. (Ed.). Ecosystems of the world: tropical savannas. Amsterdam: Elsevier. p. 427-439.

PIVELLO, VR. and COUTINHO, LM., 1996. A qualitative sucessional model to assist in the management of Brazilian cerrados. Forest Ecol. and Manag. vol. 87, no. 1-3., p. $127-138$.

RAMOS-NETO, MB. and PIVELLO, VR., 2000. Lightning fires in a Brazilian savanna National Park: rethinking management strategies. Environ. Manag., vol. 26, no. 6, p. 675-684.

RATTER, JA., RIBEIRO, JF. and BRIDGEWATER, S., 1997. The Brazilian cerrado vegetation and threats to its biodiversity. Ann. Bot., vol. 80, no. 3, p. 223-230.

REDFORD, KH. and FONSECA, GAB., 1986. The role of gallery forests on the zoogeography of the Cerrado's non-volant mammalian fauna. Biotropica, vol. 18, no. 2, p. 126-135.

RIBEIRO, JF. and WALTER, BMT., 1998. Fitofisionomias do bioma cerrado. In SANO, SM. and ALMEIDA, SP. (Ed.). Cerrado: ambiente e flora. Brasília: Embrapa. p. 89-152.

SARMIENTO, G., 1983. The savannas of tropical America. In GOODALL, DW. (Ed.). Ecosystems of the world: tropical savannas. Amsterdam: Elsevier. p. 245-288.

SILVA, JMC. and BATES, JM., 2002. Biogeographic patterns and conservation in the South American Cerrado: A tropical Savanna hotspot. Bioscience, vol. 52, no. 3, p. 225-233.

SILVEIRA, L., RODRIGUES, FHG., JACOMO, AT., 1999. Impact of wildfires on the megafauna of Emas National Park, Central Brazil. Oryx, vol. 33, no. 2, p. 108-114.

STAFFORD-SMITH, MD. and MORTON, SR., 1990. A framework for the ecology of arid Australia. J. Arid Environ., vol. 18 , no. 3 , p. $255-278$

TAINTON, NM., MORRIS, CD. and HARDY, MB., 1996. Complexity and stability in grazing systems. In HODGSON, J. and ILLIUS, AW. (Ed.). The ecology and management of grazing systems. New York: CAB International. p. 275-99.

WALKER, BH., 1987. A general model of savanna structure and function. In WALKER, BH. (Ed.). Determinants of tropical savannas. Miami: ICSU. p.1-12.

WALKER, BH., 2001. Tropical savanna. In Chapin, FS., Sala, OE. and Huber-Sannwald, E. (Ed.). Global biodiversity in a changing environment. Berlin: Springer. p. 139-156.

WALKER, BH. and NOY-MEIR, I., 1982. Aspects of the stability and resilience of savanna ecosystems. In HUNTLEY, BJ. and WALKER, BH. (Ed.). Ecology of Tropical Savannas. Berlin: Springer. p. 577-590.

WARDLE, DA., BONNER, KI. and BARKER, GM., 2000. Stability of ecosystem properties in response to above-ground functional group richness and composition. Oikos, vol. 89, no. 1, p. 11-23.

ZAR, JH., 1999. Biostatiscal analysis. Prentice Hall: Upper Saddle River. 